\title{
KOMPILASI HUKUM ISLAM SEBAGAI FIQH LINTAS MADZHAB DI INDONESIA
}

\author{
Moh. Asy'ari \\ (Sekolah Pascasarjana UIN Syarif Hidayatullah Jakarta, \\ email: Moh_asyari76@yahoo.com)
}

\begin{abstract}
Abstrak
Kebekuan perkembangan hukum Islam dari pertengahan abad IV H - XII H menimbulkan 'kegelisahan intelektual' sekaligus memancarkan semangat ijtihâd di kalangan kaum Muslim. Dalam semangat ijtihâd inilah, Indonesia berhasil menyusun KHI, yang tema utamanya adalah mempositifkan hukum Islam di Indonesia. Kitab-kitab yang digunakan dalam merumuskan KHI tersebut berjumlah 38 kitab. Dari hasil penelusuran terhadap kitab-kitab yang digunakan tersebut dapat diketahui bahwa kebanyakan dari mereka adalah kitab-kitab figh madzhab Syâfi'î. Sedangkan sebagian lainnya merupakan kitab-kitab figh madzhab Hanafî, Mâlikî, Hanbalî, Dzahirî, dan Syî́ah. Di samping itu, juga terdapat kitab-kitab perbandingan dan tanpa madzhab. Penggunaan kitab-kitab dari berbagai madzhab tersebut dapat dipahami sebagai keinginan untuk mempercepat proses taqrîb bayn alummah sehingga pertentangan antar madzhab dapat dihindari dan diarahkan kepada perpaduan dan kesatuan kaidah dan nilai.
\end{abstract}

\footnotetext{
Abstract

Coagulation of Islamic law development, in middle centuries, brings about 'intellectual curiosity' and spout out the spirit of ijtihâd (interpretation through reasoning and judgment) among Moslems. Under the spirit of ijtihâd, Indonesia had successfully constructed the Islamic Law Compilation (KHI) that upholds the main theme, it is about to make ijtihâd become the positive law in Indonesia. There were 38 kitab (Islamic books)
} 
that had been used to formulate KHI. Most of the Islamic books were books of figh (legal maxims) of Syâfi'î school. Meanwhile, the figh books of Hanafî, Mâlikî, Hanbalî, Dzahirî, and Syî́ah schools took minor role. Instead, it had been recognized comparative and non mainstream Islamic books. The use of books from various schools of thought was understandable to accelerate the process of taqrîb bayn al-ummah, in order to avoid inter-schools conflict. It was also directed to unity and harmony of rules and values.

\section{Kata-kata Kunci}

fiqh, hukum Islam, ijtihâd, madzhab, dan KHI.

\section{Pendahuluan}

Mengutip pendapat Edmund Burke, Noel J. Coulson mengatakan bahwa ahli hukum adalah sejarawan yang buruk. ${ }^{1}$ Secara substansial pernyataan tersebut mengisyaratkan kegelisahan atas sikap fuqahâ' hingga awal abad XIX M/XII H yang masih 'enggan' mencermati perkembangan sosial dan tuntutan-tuntutannya sebagai kerangka dasar pembangunan hukum Islam. Perkembangan hukum Islam dari pertengahan abad IV $\mathrm{H}$ sampai abad XII $\mathrm{H}$ yang mengalami kebekuan dan kejumudan tersebut, ternyata menimbulkan 'kegelisahan intelektual' yang melahirkan sloganslogan tajam dan semangat ijtihâd.

Ijtihâd merupakan suatu keniscayaan dalam pengembangan materi hukum Islam sesuai dengan tuntutan sosio-kultural dan kehendak sejarah yang senantiasa berubah. Karenanya, ijtihâd perlu dibuka lebar-lebar bagi kaum Muslim yang memiliki kemampuan untuk menciptakan produk figh yang dapat dipertanggungjawabkan kebenarannya. Penutupan pintu ijtihâd berarti menempatkan kaum Muslim seluruhnya dalam kebekuan dan eksklusifitas terhadap berlakunya hukum-hukum perkembangan.

${ }^{1}$ Noel J. Coulson, A History of Islamic Law (Edinburgh: Edinburgh University Press, 1964), hlm. 1 
Dalam kerangka ijtihâd inilah, Indonesia berhasil menyusun Kompilasi Hukum Islam (KHI) yang terealisasi berdasarkan SKB Ketua MA RI dan Menteri Agama RI tentang Penunjukan Pelaksana Proyek Pembangunan Hukum Islam melalui Yurisprudensi No. 07/KMA/1985 dan No. 25 tahun 1985 tanggal 21 Maret 1985.

\section{KHI: Sebuah Sistem Figh Islam Indonesia}

Tema utama KHI adalah memositifkan hukum Islam di Indonesia, ${ }^{2}$ karena substansi KHI adalah hukum Islam atau figh. ${ }^{3}$ Ini bisa dilihat pada tataran legal-formal yakni Inpres No. 1 Tahun 1991 dan Keputusan Menteri Agama No. 154 Tahun 1991 yang meletakkan label 'hukum Islam' pada buku kompilasi. Karenanya, tidak keliru apabila Bustanul Arifin menyebut KHI sebagai "figh dalam bahasa undang-undang". ${ }^{4}$

Sebagai sebuah figh, KHI merupakan produk yang berazaskan Islam dengan berbagai akulturasi dan sinkretisasinya dengan hukum adat dan kondisi sosio-kultural lokal. Ini bisa dilihat dari banyaknya pasal-pasal dalam KHI yang sesuai dengan ajaran alQur'ân dan al-Sunnah, di samping juga terdapat beberapa pasal dalam KHI yang diserap dari norma-norma hukum adat yang telah diterima oleh masyarakat Islam Indonesia. ${ }^{5}$

\footnotetext{
2 Walaupun sudah ada UU No. 1 tahun 1974 dan PP. No. 9 Tahun 1975 yang mengandung hukum material di bidang perkawinan, tetapi hal-hal yang ada di dalamnya baru merupakan pokok-pokok, belum secara menyeluruh terjabarkan ketentuan-ketentuan hukum perkawinan yang diatur dalam Islam, yang menyebabkan para hakim merujuk kepada doktrin figh. Apalagi mengenai bidang hibah, wakaf, dan kewarisan, sampai saat KHI disusun, belum diatur dan dirumuskan hukumnya secara positif dan unikatif. Lihat M. Yahya Harahap, "Informasi Materi Kompilasi Hukum Islam, Mempositifkan Abstraksi Hukum Islam", dalam Kompilasi Hukum Islam dalam Sistem Hukum Nasional, Cik Hasan Bisri (ed.) (Jakarta: Logos Wacana Ilmu, 1999), hlm., 31.

3 Tentang persamaan pengertian hukum Islam dan figh, lihat lihat Muhammad Hasbi Ash-Shiddieqy, Falsafah Hukum Islam (Jakarta: Bulan Bintang, 1993), hlm., 44. Ia mengatakan bahwa hukum Islam atau figh adalah koleksi daya upaya fuqahâ' dalam menerapkan syari'at Islam sesuai dengan kebutuhan masyarakat. Lihat Muhammad Hasbi Ash-Shiddieqy, Falsafah Hukum Islam (Jakarta: Bulan Bintang, 1993), hlm., 44.

4 Bustanul Arifin, "Kompilasi: Figh dalam Bahasa Undang-Undang", Pesantren No. 2/Vol. II/1985 (Jakarta: P3M, 1985), hlm., 25-30.

5 Bandingkan dengan A. Azhar Basyir, "Pemasyarakatan KHI melalui Jalur Pendidikan Non-Formal", Mimbar Hukum, No. 5 Tahun III 1992, yang mengatakan
} 
Upaya perumusan figh yang bernuansa khas Indonesia sesungguhnya telah dilakukan oleh Hasbi Ash-Shiddieqi dan Hazairin. Melalui proyek yang digagasnya, yakni figh Indonesia, ${ }^{6}$ Hasbi berharap dapat memecahkan berbagai persoalan hukum yang timbul di kalangan masyarakat Indonesia, sehingga figh tidak lagi dianggap oleh sebagian orang Indonesia sebagai barang antik yang layak dipajang di museum.7 Gagasan ini dilatarbelakangi oleh keinginan kaum Muslim Indonesia untuk memiliki sebuah figh yang berkepribadian Indonesia dengan melepaskan diri dari kebiasaankebiasaan Timur Tengah. ${ }^{8}$ Sedangkan Hazairin melontarkan idenya tentang madzhab nasional, yakni madzhab yang sesuai dengan kepribadian Indonesia..$^{9}$ Untuk merealisasikan gagasannya, ia selalu menyebarkan dan mengembangkan semangat ijtihâd ${ }^{10}$ di kalangan umat Islam Indonesia dan memberantas sikap taqlid yang menyebabkan stagnasi berfikir.

'Persetubuhan' ajaran Islam dengan kondisi sosio-kultural lokal dalam sebuah produk figh memang tidak bisa dielakkan, karena merupakan suatu keniscayaan dalam figh untuk memberikan ruang

bahwa KHI seluruhnya bersumber kepada hukum Islam ... dengan memperhatikan hukum yang hidup di kalangan umat Islam Indonesia dan memelihara ruh syari'at.

6 Figh Indonesia yang dimaksud dalam dalam hal ini adalah konstruksi figh yang sesuai dengan kepribadian dan karakteristik bangsa Indonesia. Lihat Hasbi, "Me'moedah'kan Umat", Panji Islam Th. VII, (Maret, 1966), hlm., 48. lihat juga idem, Sjari'at Islam Mendjawab Tantangan Zaman (Yogyakarta: IAIN, 1961), hlm., 41.

7 Hasbi, "Tugas Para Ulama dalam Memelihara dan Mengembangkan Qur'an, Hadits, dan Figh dalam Generasi yang Sedang Berkembang", dalam Panji Masyarakat, Th. XIV No. 122 (Maret, 1975), hlm., 17.

8 Nucholis Madjid, “Akar Islam: Beberapa Segi Budaya Indonesia dan Kemungkinan Pengembangannya bagi Masa Depan Indonesia" dalam Nurcholis Madjid, Islam, Kemoderenan dan Keindonesiaan, ed. Agus Edi Santoso (Bandung: Mizan, 1992), hlm., 67.

9 Istilah ini kemudian diganti sendiri olehnya dengan istilah yang lebih tepat, yakni madzhab Indonesia. Lihat Hazirin, Tujuh Serangkai tentang Hukum (Jakarta: Bina Aksara, 1985) hlm., 145. lihat juga, idem, Hukum Kekeluargaan Nasional (Jakarta: Tinta Mas, 1982), hlm., 6 dan Bismar Siregar, Prof. Dr. Hazairin, Seorang Mujahidin Penegak Hukum Berdasar Ketuhanan Yang Maha Esa", dalam Pembaharuan Hukum Islam di Indonesia in Memorium Prof. Dr. Hazairin (Jakarta: IU Press, t.th.) hlm., 4.

10 Menurut Hazairin, Ijtihâd hanya dalam bidang yang langsung menyentuh persoalan kemasyarakatan, bukan dalam bidang ibadah. Lihat Hazairin, Hukum Islam dan Masyarakat (Jakarta: Bulan Bintang, 1985), hlm., 16. 
gerak dinamis bagi perkembangan, pembaruan dan kehidupannya dari suatu masa ke masa yang lain dan dari suatu kondisi ke kondisi lainnya. Karenanya, figh merupakan suatu produk yang senantiasa hidup dan berkembang dan mampu bergumul dengan persoalanpersoalan kontemporer yang senantiasa meminta etik dan paradigma baru.

Keluasan tsarwah fighiyah ${ }^{11}$ adalah suatu bukti dari adanya ruang gerak dinamis figh. Ia merupakan implementasi obyektif dari doktrin Islam yang meskipun berdiri di atas kebenaran yang kokoh dan mutlak, juga memiliki ruang gerak dinamis bagi perkembangan, pembaruan dan kehidupan yang sesuai dengan fleksibilitas ruang dan waktu.

Munculnya dua aliran dalam fiqh, yakni ahl al-hadits dan ahl al-ra'y pada masa sighar sahabat dan tabi' in, yang berlangsung hingga awal abad II $\mathrm{H}$, ternyata sangat dipengaruhi oleh kondisi sosiokultural yang membentuk karakteristik, teori dan rumusan yang berbeda-beda, meskipun tetap berpegang kepada al-Qur'ân dan alSunnah sebagai sumber utama. Ahl $r a^{\prime} y$ dianut oleh para fuqahâ' Irak, yang secara kultural adalah daerah yang jauh dari bumi kenabian dan bumi hadits serta merupakan daerah terbuka yang banyak mendapat pengaruh peradaban dan kebudayaan lain. Fuqahâ' daerah ini sering dihadapkan kepada persoalan-persoalan baru dan untuk mengatasinya mereka terpaksa menggunakan rasio atau ijtihâd. Berbeda dengan Hijaz, tempat lahirnya ahl al-hadîts, yang masyarakatnya masih diliputi oleh suasana kehidupan sederhana seperti keadaan pada masa Nabi saw. Untuk mengatasi berbagai masalah yang muncul fuqahấ merasa cukup dengan hanya mengandalkan pemahaman literal terhadap al-Qur'ân al-Sunnah, dan ijma' sahabat.12 Dengan demikian, lahirnya dua aliran dalam figh tersebut lebih disebabkan oleh desakan-desakan kultural.

Demikian pula, apabila mencermati proses lahirnya madzhab-madzhab figh yang berkembang hingga saat ini, Hanafiyah, Mâlikiyah, Syâfi'îyah, dan Hanabilah, dapat dikatakan bahwa

11 Ini merupakan istilah yang berkembang di kalangan fuqahâ' yang diasosiasikan pada kesemarakan kajian-kajian figh, terutama pada abad II dan II H, yang tidak hanya terbatas pada persoalan-persoalan yang mereka hadapi, tetapi juga merambah kepada hal-hal yang belum terjadi.

12 Abdul Fattah, Târîkh al-Figh al-Islâmî (Mesir: Dâr al-Ma'ârif, 1981) hlm., 220-227. 
karakteristik, metode berfikir, teori, dan formula para imâm madzhab tersebut merupakan refleksi logis dari situasi dan kondisi masyarakat di mana hukum itu tumbuh. Abu Hanifah dilahirkan dan dibesarkan di Kufah di mana masyarakatnya sudah banyak mengenal peradaban dan kebudayaan, sehingga dalam memecahkan persoalan hukum ia menggunakan akal. Berbeda dengan Imâm Mâlik yang hidup di Madinah, sebuah daerah yang kehidupan masyarakatnya masih sangat sederhana dan lebih bernuansa kampung dan merupakan daerah hadits, sehingga fuqahấ di sini tidak perlu lagi memakai rasio dalam penyelesaian persoalan yang muncul. Al-Syâfi'î berfikiran moderat karena ia mengalami berbagai latar belakang kehidupan yang berbeda, mulai dari Madinah, Irak dan Mesir. Terakhir, Imâm Ahmad ibn Hanbal berfikiran fundamentalis guna menghadapi penyelewengan agama yang dilakukan oleh kaum rasionalis seperti Mu'tazilah, Qadariyah, Jahmiyah, dan Murji'ah pada periode pertengahan Dinasti Abbasiyah, ketika unsur Persia mendominasi unsur Arab. 13

\section{Fiqh Lintas Madzhab: Analisis atas Kitab-kitab Rujukan KHI}

KHI, sebagaimana dijelaskan di atas, selain substansinya diharapkan sesuai dengan ajaran Islam juga diharapkan mampu menampung nilai-nilai dan norma-norma hukum yang tumbuh, hidup dan berkembang dalam masyarakat Indonesia. Untuk memenuhi harapan tersebut, proses pembentukan KHI14 ditempuh melalui pengkajian kitab-kitab figh, penelitian yurisprudensi Peradilan Agama,15 wawancara, ${ }^{16}$ studi perbandingan, ${ }^{17}$ Bahts alMasấ $i l,^{18}$ Seminar ${ }^{19}$ dan lokakarya. ${ }^{20}$

13 Secara lengkap biografi masih-masing imâm madzhab, baca Farouq Abu Zaid, Hukum Islam, Antara Tradisionalis dan Modernis, terj., Husein Muhammad (Jakarta: P3M, 1986) hlm., 10-45.

14 Sesungguhnya, secara garis besar, tugas pokok yang harus dilaksanakan oleh Tim Pelaksana Proyek sesuai dengan SKB Ketua MA dan Menag RI. No. 07/KMA/1985 dan No. 25 Tahun 1985 adalah melakukan pengumpulan data, wawncara, lokakarya, dan studi perbandingan.

15 Penelitian terhadap Yurisprudensi Peradilan Agama ini dilakukan oleh Direktorat Pembinaan Badan Peradilan Agama Islam Depag RI terhadap 16 buku himpunan yurisprudensi, yakni (1) Empat buah buku himpunan Putusan PA/PTA terbitan tahun 1976/1977, 1977/1978, 1978/1979, dan 1980/1981, (2) Tiga buah buku 
Tulisan ini hanya difokuskan pada kitab-kitab figh yang dikaji dalam perumusan KHI yang seluruhnya berjumlah 38 kitab, yaitu al-Bâjûriy, Fath al-Mu'în, Syarqâwi 'alâ al-Tahrîr, Mughnî alMuhtâj, Nihâyat al-Muhtâj, al-Syarqâwî, I'ânat al-Tâlibîn, Tuhfah, Targî̉b al-Musytâq, Bulghah al-Sâlik, Syamsurî fì al-Farâ'id, al-Mudâwanah, Qalyûbî/Mahallî, Fath al-Wahab dengan Syarh-nya, al-Umm, Bughyat alMustarsyidîn, Bidâyat al-Mujtahid, 'Aqîdah wa al-Syarî'ah, al-Muhalla, alWajîz, Fath al-Qadîr, al-Fiqh 'alâ Madhâhib al-Arba'ah, Fiqh al-Sunnah, Kasyf al-Qinâ', Majmû'ah al-Fatâwâ ibn Taymiyah, Qawânîn al-Syar'iyyah Lî al-Sayyid Utsmân bin Yahya, al-Mughnî, al-Hidâyah Syarh al-Bidâyah Taymiyyah al-Mubtadi, Qawânîn al-Syar'iyyah Lî̀ al-Sayyid Sudâqah Dahlân, Nawâb al-Jalîl, Syarh ibn 'Abidîn, al-Muwattâ', Hâsyiyah

Himpunan Fatwa terbitan tahun 1978/1979, 1979/1980, dan 1980/1981, (3) Lima buah Yurisprudensi PA terbitan tahun 1977/1978, 1978/1979, 1981/1982, 1982/1983, dan 1983/1984, dan (4) Empat buah buku Law Report terbitan 1977/1978, 1978/1979, 1981/1982, dan 1983/1984. Lihat Ditbinbapera, Kompilasi Hukum Islam (Jakarta: Ditbinbapera, 1991/1992), hlm., 152.

16 Wawancara ini dilakukan kepada 185 ulama di 10 lokasi PTA se-Indonesia, yaitu Banda Aceh, Medan, Palembang, Padang, Surakarta, Bandung, Surabaya, Ujung Pandang, Mataram dan Banjarmasin. Ulama' tersebut berasal dari organisasiorganisasi sosial dan keagamaan Islam dan ulama' berpengaruh di luar organisasi sosial dan keagamaan dan diutamakan ulama' yang mengasuh lembaga pesantren. Wawancara ini dilakukan dengan dua cara, yakni: Pertama, mengajukan pokok-pokok masalah kepada responden secara kolektif di suatu tempat. Kedua, mewawancarai responden secara terpisah, jika cara pertama tidak memungkinkan untuk dilakukan. Lihat Bustanul Arifin,"Kompilasi: Figh dalam Bahasa UU”, hlm., 9. Lihat juga Ahmad Rofiq, Hukum Islam di Indonesia (Jakarta: Raha Grafindo Persada, 1997), hlm., 52-53.

17 Studi perbandingan ini dimaksudkan untuk mendapatkan sistem atau kaidahkaidah hukum yang paling tepat untuk diterapkan dalam konteks Indonesia. Karenanya, tiga negara Timur Tengah dipilih untuk dijadikan tempat studi perbandingan, yaitu Maroko, Turki, dan Mesir. Lihat Marzuki Wahid dan Rumadi, Figh Madzhab Negara, Kritik atas Politik Hukum Islam di Indonesia (Yogyakarta: LKiS, 2001), hlm., 158.

18 Bahth al-Masâ'il dilakukan oleh Syuriah NU Jawa Timur di tiga pondok pesantren di Jawa Timur, yaitu PP. Tambakberas, PP. Lumajang, dan PP. Sidoarjo. Lihat Ibid., hlm., 160 .

19 Seminar tersebut diselenggarakan oleh Majelis Tarjih PP. Muhammadiyah di Kampur UM Yogyakarta pada 8-9 April 1986. lihat Ibid.

${ }^{20}$ Lokakarya ini berlangsung pada 2-6 Februari 1988 di Hotel Kartika Candra, dan diikuti oleh 124 peserta yang terdiri dari para ketua umum MUI Propinsi, para ketua PTA se-Indonesia, beberapa Rektor IAIN, beberapa Dekan Fakultas Syari'ah IAIN, sejumlah ulama dan cendekiawan Muslim, dan beberapa wakil organisasi wanita. Lihat Sinar Darussalam, No. 166/167 1988, hlm., 11. 
Syamsuddîn Muhammad 'Irfân Dasûqî, Badâ'i al-Sanâ'î, Tabyîn al-Haqấ'iq, al-Fatâwâ al-Hindiyyah, Fath al-Qadîr, da Nihâyah. ${ }^{21}$

Dari 38 kitab di atas, 13 kitab, yakni al-Bajûrî, Fath al-Mu'în, Syarqâwwî̀ 'alâ al-Tahrîr, Qalyûb̂̂/Mahallî, Qawânin al-Syar'iyyah Lî̀ alSayyid Uthmân bin Yahya, Qawânîn al-Syar'iyyah Lî al-Sayyid Sudâqah Dahlân, Tuhfah, Targîb al-Musytaq, Syamsûrî fi al-Farâ'id, Bughyat alMustarsyidîn, Fath al-Wahab dengan Syarh-nya, Mughnî al-Muhtâj, dan al-Figh 'Alâ Madhâhib al-Arba'ah, telah dijadikan kitab rujukan bagi para hakim Peradilan Agama dalam memeriksa dan memutuskan perkara yang dibakukan melalui Surat Edaran Biro Peradilan Agama No. B/1/735 tanggal 18 Februari 1958 sebagai tindak lanjut PP. No. 45 tahun 1957 tentang Pembentukan Pengadilan Agama/Mahkamah Syar'iyah di Luar Jawa dan Madura. Dari ketiga belas kitab tersebut kesemuanya berbahasa Arab, kecuali Qawânîn al-Syar'iyyah Lî alSayyid Uthmân bin Yahya yang ditulis dalam bahasa Melayu Arab dan kesemuanya merupakan kitab-kitab klasik dalam madzhab Syâfi'î, kecuali al-Fiqh 'Alâ Madhâhib al-Arba'ah yang merupakan kitab komparatif (muqâranah al-madzâhib fí al-figh).

Dominannnya kitab-kitab figh madzhab Syâfi'î tersebut memang tidak bisa dielakkan mengingat mayoritas umat Muslim di Indonesia bermadzhab Syâfi'î. Ini memiliki garis linear dengan awal kedatangan Islam ke Indonesia yang dibawa oleh orang-orang Arab yang bermadzhab Syâfi'î. Keyzer, misalnya, berpandangan bahwa Islam masuk ke Indonesia pada abad I H/VII M dibawa oleh orangorang Mesir yang bermadzhab Syâfi'î. Pengikut madzhab Syâfi'î sebagai pembawa Islam ke Indonesia juga didukung oleh Nieman dan De Holander, walaupun keduanya menyebut Hadramaut (bukan Mesir) sebagai sumber datangnya Islam. Para sarjana Belanda pun seperti Pijnappel dan G.J.W. Drewes 'berhujjah' tentang pembawa Islam ke Indonesia. Menurutnya, Islam masuk ke Indonesia melalui

${ }^{21}$ Ditbinpera, Kompilasi Hukum Islam, 166-168. Selain kitab-kitan figh tersebut, penyusunan KHI juga merujuk pada fatwa yang berkembang di Indonesia melalui lembaga fatwa MUI, Bahtsul Masa'il NU, dan Majelis Tarjih Muhammadiyah. Baca Bustanul Arifin Pelembagaan Hukum Islam di Indonesia, Akar Sejarah, Hambatan dan Prospeknya (Jakarta: Gema Insani Press, 1996), hlm., 162-163 dan Abdurrahman, Kompilasi Hukum Islam di Indonesia (Jakarta: Akademika Presindo, 1995), hlm., 39-41. 
orang-orang bermadzhab Syâfi'î yang berimigrasi dan menetap di wilayah India. ${ }^{22}$

Selanjutnya, mengenai tambahan dari 13 kitab menjadi 38 kitab rujukan KHI sebagaimana disebut di atas, penulis melihat bahwa kitab-kitab tersebut tidak hanya terbatas pada kitab-kitab figh Syâfi'î saja., tetapi ada juga kitab-kitab yang berasal dari madzhabmadzhab Hanafî (al-Hidâyah dan Fath al-Qadîr), Mâlikî (al-Muwatta' dan al-Mudâwanah), dan Hanbalî (al-Mughnî dan al-Fatâwầ alHindiyah), bahkan ada yang berasal dari madzhab Dhahirî (al-Muhalla) dan Syîah (Fath al-Qadîr oleh al-Syawkanî) serta ada yang merupakan kitab perbandingan madzhab (al-Fiqh 'Alâ Madhâhib al-Arba'ah) dan tanpa madzhab (I'lâm al-Muqi'în). ${ }^{23}$

Hal tersebut menunjukkan bahwa KHI merupakan implementasi berbagai pendapat madzhab figh untuk menjawab berbagai persoalan hukum yang ada di Indonesia. Artinya, materi hukum Islam yang tertuang di dalam KHI tidak terikat pada salah satu madzhab. Ini sesuai dengan tujuan penyusunan KHI itu sendiri yang ingin mempercepat proses taqrîb bayn al-ummah 24 sehingga pertentangan antar madzhab dapat dihindari dan diarahkan kepada perpaduan dan kesatuan kaidah dan nilai.

Kemajemukan kitab rujukan KHI dari berbagai madzhab tersebut juga menunjukkan adanya pemanfaatan lembaga talfiq 25 dan

22 Lihat Azyumardi Azra, "Islam di Asia Tenggara, Pengantar Pemikiran" dalam Azyumardi Azra (ed.), Perspektif Islam Asia Tenggara (Jakarta: YOI, 1989), hlm., xi-xiii. Tentang bukti sejarah 'hujjah' para sarjana di atas, lihat Azyumardi Azra, Jaringan Ulama Timur Tengah dan Kepulauan Nusantara Abad XVII dan XVIII (Bandung: Mizan, 1994), hlm., 24-35.

23 Penyebutan kitab-kitab dari masing-masing golongan ini hanya sekedar contoh minimal.

${ }^{24}$ M. Yahya Harahap, “Informasi Materi Kompilasi Hukum Islam”, hlm., 27.

25 Talfiq dilakukan dengan cara meramu beberapa hasil ijtihâd dalam masalah tertentu menjadi suatu bentuk yang baru lihat Norman Anderson, Law Reform in the Muslim World (Syracuse: University of London Press, 1982), hlm., 55. Tentang silang pendapat para ulama mengenai boleh tidaknya bertalfiq, baca Amir BadSyah, Tafsîr al-Tahrîr, Juz IV (Mesir: Dâr al-Kutub al-Hadîthah, t.th.), hlm., 254; Ibrohim Hosen, "Bermadzhab dan Bertalfiq", dalam Jamal D. Rahman (ed.), Wacana Baru Figh Sosial (Bandung: Mizan, 1997), hlm., 128-129; dan Abdul Aziz Dahlan (ed.), "Talfiq", dalam Ensiklopedi Hukum Islam (Jakarta: Ichtiar Baru Van Hoeve, 1996), hlm., 1786-1788. 
takhayyur ${ }^{26}$ dalam formulasi hukumnya. Kedua metode ini dilakukan karena apabila menggunakan satu dari berbagai pemikiran yang ada, terlihat titik-titik kelemahan yang menyebabkan figh kehilangan aktualitasnya. Cara ini dipandang cukup efektif untuk merealisasikan kemaslahatan.

Pembentukan figh lintas madzhab melalui KHI ini bisa dipahami dari sisi sosio-kultural masyarakat Indonesia. Walaupun pada mulanya umat Muslim Indonesia terikat secara menyeluruh pada pemikiran madzhab Syâfi'î, tetapi dalam perkembangan selanjutnya terjadi berbagai bentuk perubahan. Secara umum dapat dikatakan bahwa semua ulama setelah mengenyam pendidikannya di Timur Tengah dan kembali ke tanah air semakin kaya pengetahuan dan pengalamannya dengan berbagai madzhab figh yang ada, sehingga mereka lebih terbuka (open minded) pada pemikiran figh di luar paham Syâfi'î. ${ }^{27}$

Perubahan ini memberikan pengaruh yang sangat besar terhadap perkembangan keilmuan-keislaman di perguruan tinggi Islam. Hal ini bisa dilacak melalui buku wajib dan anjuran dalam silabi IAIN, terutama Fakultas Syari'ah, yang tidak hanya bukubuku/kitab-kitab dalam paham Syâfi'î, tetapi juga kitab-kitab nonSyâfi'î, seperti Irsyâd al-Fuhûl oleh al-Syawkanî (Syî'ah Zaydiyah), alMuwâfaqât oleh al-Syatibî (Mâlikiyah), al-'Uddah oleh Abî Ya'lâ (Hanbaliyah). ${ }^{28}$ Tentu saja, perubahan ini berimplikasi pada pergeseran paradigma (Shifting paradigm) pemikiran hukum Islam kaum Muslim Indonesia, terutama alumni PTAI, yang semula sebagai penjaga ortodoksi Syâfi'îyah menuju pada penggunaan metodologi hukum yang lebih kaya dengan pemikiran berbagai madzhab.

\footnotetext{
26 Takhayyur merupakan metode yurisprudensi di mana seorang Muslim dalam suatu situasi spesifik diizinkan keluar dari interpretasi madhhab hukumnya sendiri untuk mengikuti salah satu dari tigas madhhab Sunni lainnya. Eksploitasi metode ini pada periode moderen Islam terlihat dengan diperluas cakupannya untuk memilih pendapat di luar madhhab Sunni atau pendapat fuqahấ sebelum terkristalnya madhhab atau pendapat fuqahâ' belakangan. Lihat Anderson, Law Reform, hlm., 51.

27 Amir Syarifuddin, Pembaharuan Pemikiran Hukum Islam (Jakarta: PT. Raja Grafindo Persada, 1999), hlm., 127.

${ }^{28}$ Lihat Ditjen Pembinaan Kelembagaan Agama Islam Depag RI., Topik Inti Kurikulum Nasional Perguruan Tinggi Agama Islam, Fakultas Syari'ah (Jakarta: Proyek Pengembangan Pendidikan Tinggi Agama Islam, 1998).
} 


\section{Penutup}

Dari paparan di atas dapat dikatakan bahwa sesungguhnya KHI merupakan produk figh yang berciri khas Indonesia dan terlepas dari bingkai pemikiran salah satu madzhab. Ia mencoba mengakomodasi seluruh khazanah pemikiran para fuqaha baik yang terdoktrin dalam sebuah madzhab maupun yang tidak bermadzhab. Ciri khas Indonesia dari KHI dapat dilihat dari materi hukum di dalamnya yang banyak menyerap norma-norma hukum adat yang berkembang dan diterima oleh kaum Muslim Indonesia. Sedangkan model figh lintas madzhab yang dilekatkan kepadanya dapat ditelurusuri melalui kitab-kitab rujukannya yang tidak terikat pada salah satu madzhab figh yang ada.

\section{Daftar Pustaka}

Abdurrahman, Kompilasi Hukum Islam di Indonesia. Jakarta: Akademika Presindo, 1995

Anderson, Norman. Law Reform in the Muslim World. Syracuse: University of London Press, 1982

Arifin, Bustanul. "Kompilasi: Fiqh dalam Bahasa Undang-Undang", Pesantren No. 2/Vol. II/1985 (Jakarta: P3M, 1985), hlm., 25-30.

Arifin, Bustanul. Pelembagaan Hukum Islam di Indonesia, Akar Sejarah, Hambatan dan Prospeknya. Jakarta: Gema Insani Press, 1996

Ash-Shiddieqy, Muhammad Hasbi. Falsafah Hukum Islam. Jakarta: Bulan Bintang, 1993

Ash-Shiddiqy, Muhammad Hasbi, “Tugas Para Ulama dalam Memelihara dan Mengembangkan Qur'an, Hadits, dan Figh dalam Generasi yang Sedang Berkembang", dalam Panji Masyarakat, Th. XIV No. 122 (Maret, 1975), hlm., 17.

Ash-Shiddiqy, Muhammad Hasbi. "Me'moedah'kan Umat", Panji Islam Th. VII,. Maret, 1966.

Ash-Shiddiqy, Muhammad Hasbi. Sjari'at Islam Mendjawab Tantangan Zaman. Yogyakarta: IAIN, 1961

Azra, Azyumardi. "Islam di Asia Tenggara, Pengantar Pemikiran" dalam (ed.) Azyumardi Azra, Perspektif Islam Asia Tenggara. Jakarta: YOI, 1989 
Azra, Azyumardi. Jaringan Ulama Timur Tengah dan Kepulauan Nusantara Abad XVII dan XVIII. Bandung: Mizan, 1994

Badsyah, Amir. Tafsîr al-Tahrîr, Juz IV. Mesir: Dâr al-Kutub alHadithah, t.th.

Basyir, A. Azhar. "Pemasyarakatan KHI melalui Jalur Pendidikan Non-Formal", Mimbar Hukum, No. 5 Tahun III 1992

Bismar Siregar, "Prof. Dr. Hazairin, Seorang Mujahidin Penegak Hukum Berdasar Ketuhanan Yang Maha Esa", dalam Pembaharuan Hukum Islam di Indonesia in Memorium Prof. Dr. Hazairin. Jakarta: IU Press, t.th.

Coulson, Noel J. A History of Islamic Law. Edinburgh: Edinburgh University Press, 1964

Dahlan, Abdul Aziz, "Talfiq", dalam Ensiklopedi Hukum Islam. Jakarta: Ichtiar Baru Van Hoeve, 1996

Ditbinbapera, Kompilasi Hukum Islam. Jakarta: Ditbinbapera, 1991/1992

Ditjen Pembinaan Kelembagaan Agama Islam Depag RI., Topik Inti Kurikulum Nasional Perguruan Tinggi Agama Islam, Fakultas Syari'ah. Jakarta: Proyek Pengembangan Pendidikan Tinggi Agama Islam, 1998.

Fattah, Abdul. Târîkh al-Fiqh al-Islâmî. Mesir: Dâr al-Ma'ârif, 1981

Harahap, M. Yahya. "Informasi Materi Kompilasi Hukum Islam, Mempositifkan Abstraksi Hukum Islam", dalam Kompilasi Hukum Islam dalam Sistem Hukum Nasional, (ed.) Cik Hasan Bisri. Jakarta: Logos Wacana Ilmu, 1999

Harahap, M. Yahya. "Informasi Materi Kompilasi Hukum Islam"

Hazairin, Hukum Islam dan Masyarakat. Jakarta: Bulan Bintang, 1985

Hazairin, Hukum Kekeluargaan Nasional. Jakarta: Tinta Mas, 1982.

Hazairin, Tujuh Serangkai tentang Hukum. Jakarta: Bina Aksara, 1985)

Hosen, Ibrohim. "Bermadzhab dan Bertalfiq", dalam Jamal D. Rahman (ed.), Wacana Baru Figh Sosial. Bandung: Mizan, 1997

Madjid, Nurcholis. "Akar Islam: Beberapa Segi Budaya Indonesia dan Kemungkinan Pengembangannya bagi Masa Depan Indonesia" dalam Nurcholis Madjid, Islam, Kemoderenan dan Keindonesiaan, ed. Agus Edi Santoso. Bandung: Mizan, 1992

Rofiq, Ahmad. Hukum Islam di Indonesia. Jakarta: Raja Grafindo Persada, 1997 
Moh. Asy'ari

Syarifuddin, Amir. Pembaharuan Pemikiran Hukum Islam. Jakarta: PT. Raja Grafindo Persada, 1999

Wahid, Marzuki dan Rumadi. Figh Madzhab Negara, Kritik atas Politik Hukum Islam di Indonesia. Yogyakarta: LKiS, 2001

Zaid, Farouq Abu. Hukum Islam, Antara Tradisionalis dan Modernis, terj., Husein Muhammad. Jakarta: P3M, 1986 